\title{
RELATIONSHIP BETWEEN SITE INDEX AND FOLIAGE NITROGEN AT TWO CROWN LEVELS FOR MATURE BLACK SPRUCE ${ }^{1}$
}

\author{
By J. D. GAGNON ${ }^{2}$
}

\begin{abstract}
The concentration of nitrogen in current year lateral needles of 122 mature dominant and codominant black spruce trees (Picea mariana Mill.) growing on different site qualities has been studied. Analyses carried out on needles collected at the end of the growing season and within two feet of both the top and base of the crown indicated that samples obtained from either position on the crown can be related to site index or site quality. It seems, therefore, that the concentration of nitrogen in needles from the lower branches is as good a criterion of growth or productivity as that in the needles from the upper branches.
\end{abstract}

\section{INTRODUCTION}

It is generally agreed that the concentration of nitrogen in needles of many conifers is directly related to tree growth $(2,3,7,8,9,11,16,18,19$ 20,25 ). However opinions are apparently conflicting with respect to the position on the crown where samples must be collected to obtain such a relationship.

According to Leyton and Armson (10) whose opinions are now shared by: many $(12,19,24)$, current year needles from as near the terminal shoot as possible, provide the best material for foliar analysis in relation to tree growth, and they claim that if Aaltonen (1) did not find a relation between trees from different site qualities it was because he used needles collected from the lower branches. Strebel (15) reported that needles of terminal shoots from lower whorls have sometimes higher and sometimes lower nitrogen concentration than needles from the first whorl. Although he has shown that the percent of nitrogen tends to increase with greater distance from the base of the tree, Ovington (13) found it to change irregularly along the length of the bole. Will (23) observed no variation in needle nitrogen of Monterey pine at different heights within the crown while White (21) recommended sampling at mid-crown position. Recent foliar analysis by Swan (16) suggests that nitrogen content in needles from the lower crown of planted white spruce parallels vigour classes of trees.

The purpose of this study was to determine the extent to which the concentration of nitrogen in needles of mature black spruce growing on different site qualities was related to site index, and to determine the relationship between nitrogen levels in the upper and lower crown of the tree.

\footnotetext{
${ }^{1}$ Department of Forestry, Canada, Forest Research Branch Contribution No. 560.

${ }^{2}$ Research Officer, For. Res. Br., Dept. of Forestry, Box 35, Sillery, P.Q.
} 


\section{Materials and Methods}

In September 1961, 122 mature dominant and codominant black spruce were felled in twelve widely separated localities of the Quebec Laurentide Park, in Forest Section B. 1a of the boreal forest region (14). These trees were from three different stands in each of four black spruce sites belonging to distinct site $^{13}$ qualities as described by Linteau (11). In each stand ten trees were cut (in one case, twelve previously felled trees were used) and their heights recorded. Current year needles were then stripped from lateral branches located within two feet of both the top and the base of the crown and allowed to air-dry. Root-collar discs were taken at six inches above ground level and retained for age counts. Age was determined along an average radius by means of a binocular microscope. Economic age, that is, total age minus an allowance for initial suppression, if any, was used in the present study. Individual trees were considered as sample units, and their identity was maintained throughout the analysis.

The needles collected were ground in a 40-mesh Wiley cutting mill, ovendried at $65^{\circ} \mathrm{C}$ for 12 hours, and analysed for nitrogen content using the Kjeldahl method (6).

Most studies dealing with foliar nitrogen and its relation to tree growth have been conducted on uniform planting sites with trees of the same age and have used actual height growth as the dependent variable. However, in natural forests, individual tree age varies slightly in even-aged stands and very widely in uneven-aged stands. Therefore, in the present study, site index, i.e. dominant height at an index age of 50 years, was used as the expression of tree growth and as the independent variable.

\section{RESULTS}

Average site index and mean values of the nitrogen concentration at the two crown levels for each of the four site types sampled and defined on the basis of vegetation are shown in Table 1.

TABLE 1

Average Site Index On Each Site Type, And Means And Standard Errors Of Means Of Concentration Of Nitrogen In Upper ANd LOWER WHORLS NEEDLES

\begin{tabular}{lccccc}
\hline \multicolumn{1}{c}{ Site type } & $\begin{array}{c}\text { Number } \\
\text { of } \\
\text { samples }\end{array}$ & $\begin{array}{c}\text { Number } \\
\text { of } \\
\text { repli- } \\
\text { cations }\end{array}$ & $\begin{array}{c}\text { Average } \\
\text { site } \\
\text { index }\end{array}$ & \multicolumn{2}{c}{$\begin{array}{c}\text { N Concentration - Per Cent } \\
\text { Dry Weight }\end{array}$} \\
\hline Sph-Carex & 32 & 3 & 12.6 & $1.04 \pm 0.02$ & Upper Whorls \\
Sph-Rubus & 30 & 3 & 17.0 & $1.12 \pm 0.04$ & $1.00 \pm 0.02$ \\
Sph-Cornus & 30 & 3 & 24.9 & $1.23 \pm 0.01$ & $1.12 \pm 0.02$ \\
Hypnum & 30 & 3 & 33.0 & $1.29 \pm 0.02$ & $1.17 \pm 0.02$ \\
\hline
\end{tabular}

Statistical analysis of the differences in concentration of nitrogen in needles collected in different vegetative site types and at the two crown levels is presented in Table 2.

\footnotetext{
${ }^{3}$ The site types were Sphagnum-Carex (non merchantable, site class V), Sphagnum-Rubus (site class IV), Spbagnum-Cornus (site class III) and Hypnum (site class II).
} 
TABLE 2

Analysis Of Variance Of Nitrogen In Different Site Types And At Two Crown LeVels

\begin{tabular}{lcccc}
\hline Source of variation & $\begin{array}{c}\text { Degrees } \\
\text { of } \\
\text { freedom }\end{array}$ & $\begin{array}{c}\text { Sum } \\
\text { of } \\
\text { squeres }\end{array}$ & $\begin{array}{c}\text { Mean square } \\
\text { of } \\
\text { variance }\end{array}$ & $\begin{array}{c}\text { F Ratio of } \\
\text { niean } \\
\text { squares }\end{array}$ \\
\hline Between site types & 3 & .20796 & .06932 & $22.0 * * *$ \\
Between crown levels & 1 & .07370 & .07370 & $23.4 * *$ \\
Error & 19 & .05980 & .00314 & - \\
\hline Total & 23 & .34146 & - & - \\
\hline
\end{tabular}

*** Significant at more than the 1 per cent level.

Highly significant differences in nitrogen level were found between site types and between needles collected in upper and lower whorls.

The relationship between concentration of nitrogen in the needles at two crown levels and the site index of individual trees is shown in Figure 1. The nitrogen level in the upper crown is expressed by the equation:

(1) $\log . \% \mathrm{~N}=.208 \log$. site index -.210 and the lower level by the equation:

(2) $\log . \% \mathrm{~N}=.218$ log. site index -.267

The standard errors of estimate in logarithmic units are similar at both levels of crown ( 0.049 for the upper and 0.048 for the lower level) indicating that material from either level can be used with confidence. The nitrogen concentration at the upper level is, however, significantly higher than that at the lower level. The slope of the sample regression lines being almost identical, the relationship between upper and lower whorls needle nitrogen could be expressed simply by the equation:

(3) \% upper $\mathrm{N}=\%$ lower $\mathrm{N}+11 \%$

\section{DISCUSSION}

In interpreting these results, one must remember that considerable uncertainty exists regarding the uptake of nutrients by trees. Unlike annual plants the size of a tree and its current growth at any time depend upon its past history over a long period of years; for example, the concentration of nitrogen determined in current year needles at one time during the life of a tree may reflect the growth conditions which prevailed that year, which in turn depends on food stored in previous years. Furthermore, tree growth is not a function of the uptake of nutrients alone, but of many other factors, the complex of which, according to Cain (4), is almost insoluble in a mathematical sense and complicated enough to prompt Wilde (22) to warn of the dangers in the use of foliar analysis in silvicultural practice. However, foliar analysis does provide some better appreciation of the relationships between nutrients uptake and tree growth.

The apparent conflicting opinions with respect to the position on the crown where samples must be collected is attributed to differences in photosynthesis. According to White (21) lower whorls are very unrepresentative as to leaf content because they carry on little photosynthesis. This may be 


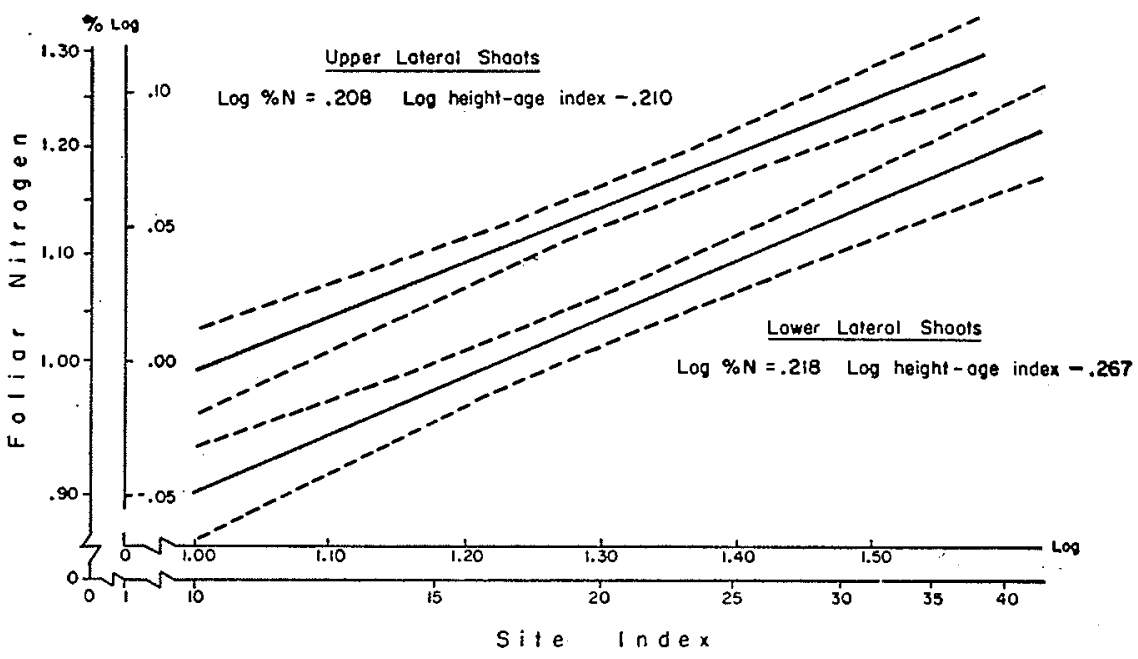

Figure 1: Lineor regressions of folior nitrogen on site index for 122 individuol trees, ond ronges within which the true regression lines probobly lie for odds of 19 to $r$,

true in plantations where, at the early stage, lower tree branches have a strong tendency to occupy all the open space. Later on, new younger branches shade the lower ones to a point where photosynthesis is practically nil. However, mature stands of black spruce, especially those on swampy soils, are normally rather open and the lower branches of dominant and codominant trees receive much light. In short, the relationship between nitrogen content of the lower branches and rate of tree height growth may be obscured in dense plantations but not in open stands, due to light intensity, effects on apparent photosynthesis as reported by Clark (5).

The fact that concentration of nitrogen in the current-year needles collected from the bottom two feet of crown can be significantly related to tree growth has a practical application. Instead of felling or climbing up trees to obtain suitable material for foliar analysis, one needs only to strip off needles from lower branches. Most of the lower black spruce branches are inclined downward and are quite accessible.

The findings that, in general, current-year needles collected from the uppermost lateral shoots contained more nitrogen than those collected from the lowermost lateral shoots (Fig. 1), agree with those of Leyton and Armson (10) and with most reports of previous investigators. Furthermore our data have recently been confirmed by Dr. J. Beaton ${ }^{4}$ working on Douglas fir. The concentration of nitrogen in needles from both positions on the crown was found to vary also with site quality as assessed by the site index of the stands (Table 1).

${ }^{4}$ Personal communication from J. H. G. Smith, editor of the Forestry Chronicle. 


\section{RESUME}

Cette étude a trait à une analyse du contenu en azote des aiguilles de 122 épinettes noires (Picea mariana Mill.) échantillonnées parmi l'étage dominant et codominant de peuplements croissant dans des stations de productivité variée. Des échantillons de l'année courante ont été prélevés des rameaux latéraux situés à moins de deux pieds de l'extrémité de la cime de l'arbre et à moins de deux pieds de la base de la cime.

L'analyse a démontré que le contenu en azote des aiguilles des arbres étudiés était étroitement lié à l'indice de hauteur de ces derniers, et reflétent la productivité des stations concernées. Il ressort aussi de cette étude que, dans les limites de l'expérience, un échantillon prélevé du niveau le plus accessible de la cime est aussi valable que s'il est prélevé à la partie supérieure de l'arbre.

\section{CONCLUSIONS}

From the results of this investigation, it can be concluded that, within the range of the sampling:

1. There is a relationship between growth as indicated by the site index and the concentration of nitrogen in needles of mature black spruce growing in natural stands.

2. The concentration of nitrogen in lateral needles collected from either within two feet of the top or two feet from the base of the crown of mature black spruce can equally be related to site quality and to site index of individual trees.

3. The nitrogen present in needles from uppermost lateral shoots was found to be .11 per cent higher than in needles collected from lowermost lateral shoots of the crown.

\section{ACKNOWLEDGEMENTS}

The author is grateful to Mr. R. J. Hatcher for reviewing the manuscript, to Mr. Antoine Jean for technical assistance and Dr. P. J. Rennie of the Petawawa Forest Experiment Station for helpful comments and criticisms.

${ }^{1}$ AALTONEN, V. T. 1950. Die Blattanalyse als Bonitierungsgrundlage des Walbdobens. Commun. Inst. for Fenn. 37:1-41.

2 ANONYMOUS. 1957/58. Growth of Norway spruce on mineral soils. Rep. Macaulay Inst. Soil Res. 1957/58. Cited from Forestry Abstract 20 (4256):523. 1959.

${ }^{3}$ ARMSON, K. A. 1959. An example of the effect of past use of land on fertility levels and growth of Norway spruce (Picea abies L. Karst) Tech. Rept. No. 1. Faculty of Forestry, University of Toronto.

${ }^{3}$ CAIN, S. A. 1944. Foundation of plant geography. Harper and Brothers, New York.

${ }^{5}$ CLARK, J. 1961. Photosynthesis and respiration in white spruce and balsam fir. Tech. Publication No. 85. State University College of Forestry at Syracuse University, New York.

'COLE, J. O., and PARKS, C. P. 1946. Semimicro-Kjeldahl procedure for control laboratories. Anal. Chem. 18,61 .

${ }^{7}$ LEAF, A. L. 1956. Growth of forest plantations on different soils of Finland. For. Sci. $2(2): 121-126$

${ }^{s}$ LEYTON, L. 1948. Mineral nutrient relationships of forest trees. For. Abstr. 9(4):399-408.

${ }^{\circ}$ LEYTON, L. 1956. The relationship between the growth and mineral composition of the foliage of Japanese larch (Larix leptolepsis Murr.). Plant and Soil 7:167-177.

${ }^{10}$ LEYTON, L., and ARMSON, K. A. 1955. Mineral composition of the foliage in relation to the growth of Scots pine, For. Sci, 1:210-218.

${ }^{1}$ LINTEAU, A. 1955. Forest sice classification of the northeastern coniferous section boreal forest region Quebec. Can. Dept. of Norchern Affairs and National Resources, For. Res. Div., Ottawa. Bull. 118. 
${ }^{10}$ ORMAN, H. R., and WILL, G. M. 1960. The nutrient content of Pinus radiata trees. N.Z. J. Sci. $3(3): 510-522$.

${ }^{14}$ OVINGTON, J. D. 1957. The volatile matter, organic carbon and nitrogen contents of tree species grown in close stands. New Phytol. 56(1):1-11.

${ }^{14}$ ROWE, J. S. 1959. Forest regions of Canada. Can. Dept. Northern Affairs and National Resources. Bull. 123.

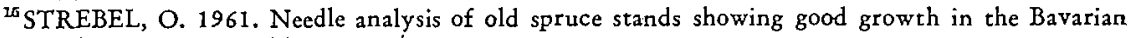
Alps. Forstwiss. Cbl. $80(11 / 12): 344-352$.

${ }^{10} \mathrm{SWAN}, \mathrm{H}$. S. D. 1962. The mineral nutrition of the Grand'Mère plantations. Woodlands Research Index No. 131. Pulp and Paper Res. Inst. of Canada.

${ }^{17}$ WEETMAN, G. F, 1961. The nitrogen cycle in temperate forest stands. Res. Note 21. Pulp and Paper Res. Inst. of Canada, Montreal.

${ }^{18}$ WEETMAN, G. F. 1962. Nitrogen relations in a black spruce (Picea mariana Mill.) stand subject to various fertilizer and soil treatments. Woodlands Research Index No. 129. Pulp and Paper Res. Inst. of Canada, Montreal.

${ }^{10}$ WEHRMANN, J. 1957. The $\mathrm{N}$ content of spruce needles in relation to the $\mathrm{N}$ supply of the trees. Mitt. StForstverw. Rayerns. No. 29:62 72. Cited from: Forestry Abstracts 19(1473): 178. 1958.

${ }^{20}$ WEHRMANN, J. 1959. The mineral nutrition of P. sylvestris stands in Bavaria. Forstwiss. Cbl. $78(5 / 6): 129-149$.

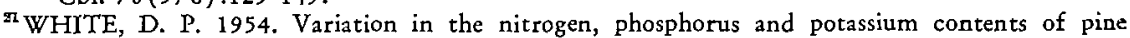
needles with season crown position and sample treatment. Proc. Soil Sci Soc. Amer. $18: 326-330$.

${ }^{2}$ WILDE, S. A. 1958. Diagnosis of nutrient deficiencies by foliar and soil analyses in silvicultural practice. First North American Forest Soils Conference, Sept. 8-11, 1958. Agric. Expt. Sta., Michigan State University. East Lansing, Michigan, U.S.A.

WILL, G. M. 1957. Variations in the mineral content of Radiatad pine needles with age and position in tree crown. Res. Note N.S. For. Serv. No. 11, 699-706.

${ }^{2}$ WRIGHT, T. W., and G. M. WILL. 1958. The nutrient content of Scots and Corsican pines growing on sand dunes. Forestry 31: 13-25.

${ }^{25}$ Zottl, Von H. 1960. The supply of mineral nitrogen in Bavarian spruce and pine stands. Forstwiss. Cbl. 79:221-236. 